\title{
Antimicrobial activity of the essential oil of Cymbopogon citratus (DC) Stapf. on Staphylococcus spp., Streptococcus mutans and Candida spp.
}

\begin{abstract}
ALMEIDA, RBA ${ }^{1 *}$; AKISUE, G²; CARDOSO, LML; JUNQUEIRA, JC'; JORGE, AO C ${ }^{1}$ ${ }^{1}$ Department of Biosciences and Oral Diagnosis, School of Dentistry of São José dos Campos, São Paulo State University / UNESP, 12245-000, São José dos Campos, SP, Brazil. ${ }^{2}$ Laboratory of Pharmacognosy and Medicinal Plants, Faculty of Pindamonhangaba, São Paulo / FAPI, CEP, Pindamonhangaba, SP, Brazil. *Corresponding author: Rosilene B. de Aguiar Almeida. Department of Biosciences and Oral Diagnosis, School of Dentistry of São José dos Campos, São Paulo State University / UNESP, Avenue Francisco José Longo 777, São Dimas, São José dos Campos, CEP: 12245-000, SP, Brazil, Tel: +55 12 39479033, Fax: +55 12 39479010, E-mail: rosileneaguiar@gmail.com
\end{abstract}

\begin{abstract}
RESUMO: Atividade antimicrobiana do óleo essencial de Cymbopogon citratus (DC) Stapf. sobre Staphylococcus spp., Streptococcus mutans e Candida spp.

As ações fungicida, antibacteriana e anti-inflamatória são propriedades importantes que vêm sendo investigadas em espécies medicinais. O objetivo do presente trabalho foi o de avaliar a atividade antimicrobiana do óleo essencial de Cymbopogon citratus (DC) Stapf. (capim-limão) sobre cepas de Staphylococcus spp., Streptococcus mutans e Candida spp. em crescimento planctônico e em biofilme. Para estudo dos micro-organismos em crescimento planctônico foram determinadas a Concentração Inibitória Mínima (CIM) e a Concentração Microbicida Mínima (CBM) de 9 cepas clínicas e, para cada espécie, uma ATCC (American Type Culture Collection) de: C. albicans, C. tropicalis, C. glabrata, S. aureus, S. epidermidis e S. mutans. Para a avaliação dos efeitos dos óleos essenciais em biofilme foram utilizadas cepas padrão de S. aureus (ATCC 6538), S. mutans (ATCC 35688) e C. albicans (ATCC 18804). O biofilme foi formado em corpos-de-prova de resina acrílica com os micro-organismos isolados ou em associações. O número de unidades formadoras de colônias obtidas em cada biofilme (UFC/ $\mathrm{mL}$ ) foi submetido ao teste $t$ de Student. Os resultados demonstraram que o óleo essencial de Cymbopogon citratus apresentou atividade microbiostática e microbicida para todas as cepas analisadas. As médias de UFC/ml para o biofilme de $S$. aureus, S. mutans e C. albicans, isolados ou associados, foram menores no grupo tratado com óleo essencial em relação ao grupo controle.
\end{abstract}

Palavras-chave: Biofilme; Óleo essencial; Cymbopogon citratus, Candida spp.; Staphylococcus spp.; Streptococcus mutans.

\begin{abstract}
Antimicrobial activity of the essential oil of Cymbopogon citratus (DC) Stapf. on Staphylococcus spp., Streptococcus mutans and Candida spp. Medicinal plants with fungicide action, antibacterial and anti-inflammatory effects are under investigation. The main purpose of this work was to evaluate the antimicrobial activity of the essential oil from Cymbopogon citratus (DC) Stapf. on strains of Staphylococcus spp., Streptococcus mutans and Candida spp. with planktonic and biofilm growth. To study the micro-organisms in planktonic cells, the minimal inhibitory concentration (MIC) and minimal bactericidal concentration (MBC) were determined by using 9 clinical strains for each species and 1 ATCC (American Type Culture Collection) from C. albicans, C. tropicalis, C. glabrata, S. aureus, S. epidermidis and $S$. mutans. In order to evaluate the effects of the essential oils on biofilms, strains of $S$. aureus (ATCC 6538), S. mutans (ATCC 35688) and C. albicans (ATCC 18804) were used. The biofilm was formed on acrylic resin discs with isolated micro-organisms or in associations. The number of colony-forming-units (CFU) obtained in each biofilm (CFU/ml) was submitted to Student's t statistical test. The results demonstrated that the essential oil of Cymbopogon citratus showed microbiostatic and microbicidal activity against all tested strains. The average CFU/ml for the biofilm of $S$. aureus, $S$. mutans and $C$. albicans, whether isolated or in association, was lower in the group treated with essential oil than in the control group.
\end{abstract}

Keywords: Antimicrobial; Biofilm; Essential oil; Candida spp.; Staphylococcus spp.; Streptococcus mutans.Streptococcus mutans.

Recebido para publicação em 20/09/2011

Aceito para publicação em 23/01/2013

Rev. Bras. PI. Med., Campinas, v.15, n.4, p.474-482, 2013. 


\section{INTRODUCTION}

In reality it is rare to find an ecological niche where only one organism is present or where only a single organism is causing a particular effect. In nature, great part of micro-organisms is often organized by what are known as biofilm (Burton \& Engelkirk, 2004). The biofilm is formed by a diverse community of micro-organisms that accumulate in hard tissues as a film, embedded in a matrix of extracellular polymers from the host and microorganism (Marsh, 2004).

Validation and selection of primary screening assays are pivotal to guarantee selection of extracts or molecules with relevant pharmacological action. Primary bioassays are generally designed for rapid screening of large numbers of products or extracts. They are simple, easy to implement and produce results quickly and preferably at low cost. Compounds or extracts with a specific activity at a non-toxic dose, need further evaluation in secondary or specialized in vitro bioassays and in animal models (Verkman, 2004).

Natural products, either as pure compounds or as standardized plant extracts, provide unlimited opportunities for new drug leads because of the unmatched availability of chemical diversity (Jeon et al., 2011; Cos et al., 2006). Research on new antimicrobial substances must therefore be continued and all possible strategies should be explored. Besides small molecules from medicinal chemistry, natural products are still major sources of innovative therapeutic agents for various conditions, including infectious diseases (Clardy \& Walsh, 2004).

The genus Staphylococcus has important virulence properties and causes a wide range of human infection diseases including pneumonia, endocarditis, periodontal diseases and others (Baba et al., 2008; Wertheim et al., 2005). Both oral cavity and subgingival pocket are ecological niches conducive for hosting micro-organisms that may act as opportunistic pathogens, such as Staphylococcus aureus and especially methicillinresistant Staphylococcus aureus (MRSA). Early detection of MRSA is a matter of concern to Public Health (Cuesta et al., 2011). Heller et al. (2012) evaluated the microbial profiles in individuals diagnosed as having chronic periodontitis or generalized aggressive chronic periodontitis. In the case of chronic periodontitis, it was found predominantly Capnocytophaga ochracea, Fusobacterium periodonticum, Staphylococcus aureus and Veillonella parvula.

Streptococcus mutans and Streptococcus sobrinus are the major etiological agents of development of dental caries of smooth surface. The accumulation of streptococci on the tooth surface is considered a critical factor in the development of cariogenic biofilms (O'Toole et al., 2000).

The Candida species are opportunistic fungal pathogens that can cause local or systemic infections in humans with predisposing factors, such as the use of dental prostheses, prolonged treatment with antibiotics, or a compromised immune system (Duarte et al., 2005).

Yeasts can also be isolated from the biofilm (Sen et al., 1997) and attach to the bacterial species (Nikawa et al., 2001, Arendorf \& Walker, 1980). Biofilms of Candida albicans, Candida parapsilosis, Candida glabrata and Candida tropicalis are associated with high indices of hospital morbidity and mortality. Major factors involved in the formation and growth of Candida biofilms are the chemical composition of the medical implant and the cell wall adhesions responsible for mediating Candida-Candida, Candida-human host cell and Candida-medical device adhesion (Cuéllar-Cruz et al., 2012). Baena-Monroy et al. (2005) found that Candida albicans, Staphylococcus aureus and Streptococcus mutans frequently colonize the oral mucosa of patients that make use of dental prosthesis. This illness-bearing condition is more frequent in patients with denture stomatitis, even though dental prosthesis colonization is lower than in the oral mucous.

The use of antimicrobial agents helps in chemical removal of the biofilm, preventing the installation of dental caries and periodontal diseases, but its frequent use can lead to development of resistant species, which now has caused great clinical concern (Moran et al., 1992). Thus, it is necessary to develop alternative treatments with powerful antimicrobial activity that can interfere with the dynamics of biofilm formation. The validation of the use of medicinal plants depends on the systematic investigation carried out with chemical methodology, pharmacology and microbiology, which along with other factors will result in herbal medicine (Rojas et al., 1992).

Investigations towards the antipathogenic potential of natural products may open new avenues for drug development in the control of antibiotic resistant pathogens (Rasmussen \& Givskov, 2006).

The specie Cymbopogon citratus (DC) Stapf., known as lemon-grass, is a producer of essential oil with commercial value (Lewinsohn et al.,1998). It presents antifungal properties (Khan \& Ahmad, 2012; Irkin \& Korukluoglu, 2009; Onawunmi, 1989), antibacterial properties (Cimanga et al., 2002), diuretic action (Gálvéz et al., 1998), anticarcinogenic role (Puatanachokchai et al., 2002), gastroprotection mechanisms (Fernandez et al., 2012) and protective effect against parasites (Santoro et al., 2007).

In the search for preventive methods in

Rev. Bras. PI. Med., Campinas, v.15, n.4, p.474-482, 2013. 
dentistry, studies of medicinal plants with fungicide properties, antibacterial and anti-inflammatory are being developed. Some products of plant origin are used in oral hygiene with the advantage of not having side effects compared to synthetic products (Moran et al., 1992).

Considering the great use of plants as medicinal substances in the Brazilian popular medicine, it is critical to investigate their biological and chemical properties in order to not only help to enhancing our understanding of the therapeutic potential of these natural products, but also how to make them more effective pharmacological agents. Thus, the purpose of this study was to evaluate in vitro effects of essential oil of Cymbopogon citratus (DC) Stapf. on strains of Staphylococcus species, S. mutans and Candida spp. in biofilm and planktonic growth.

\section{MATERIALS AND METHODS}

\section{Botanical material}

The specie Cymbopogon citratus (DC) Stapf. was collected on the Site Pinheiros, in the locality of Alto-do-Sarapuí, Elvio village, district of Piedade, São Paulo, Brazil, between 9:00 and 10:00 am., in the first week on September, 2007. The voucher specie was deposited at the herbarium SPF, Department of Botany, University of São Paulo, Matão Street, 277, building Sobre-as-Ondas, CEP 05508-090, São Paulo, Brazil, under numbers G. Akisue 031 (SPF).

\section{Essential oil}

The essential oil was extracted from leaves of $C$. citratus. The oil extraction was performed at the Laboratory of Pharmacognosy and Medicinal Plants, Faculty of Pindamonhangaba (FAPI) by the technique of hydrodistillation in a modified Clevenger extractor (Clevenger, 1928).

\section{Micro-organisms}

In the determination of the minimum inhibitory concentration (MIC) it was used 54 clinical strains and 1 ATCC from each specie $S$. aureus (ATCC 6538), S. epidermidis ATCC (12228), S. mutans (ATCC 35688), C. albicans (18804), C. tropicalis (ATCC 13803) and C. glabrata (ATCC 90030), which constituted a total of 60 samples. These clinical strains and standards were gathered from the Laboratory of Microbiology, Faculty of Dentistry of São José dos Campos / UNESP. Only the clinical strains were isolated from oral cavity from healthy individuals. This work was approved by the Research Ethics, Faculty of Dentistry of São José dos Campos / UNESP (01/ 2008-PH/CEP).
To assess the effects of essential oils on the biofilm three reference strains [American Type Culture Collection (ATCC)], C. albicans (ATCC 18804), S. aureus (ATCC 6538), and S. mutans (ATCC 35688), were used in the study.

\section{Micro-organisms suspension}

Strains of Staphylococcus and Streptococcus were grown in Brain Heart Infusion agar (BHI, Difco, Detroit, USA) and strains of Candida in Sabouraud dextrose agar (Difco, Detroit, USA) at $37^{\circ} \mathrm{C}$ for 48 hours. Strains of Streptococcus were incubated in microaerophilic conditions $\left(5 \%\right.$ de $\left.\mathrm{CO}_{2}\right)$. After this period, the microbial colonies were suspended in sterile solution of $\mathrm{NaCl} 0,9 \%$ and standardized in $10^{6}$ cells/ml by means of a spectrophotometer (Micronal - B582, São Paulo, Brazil). The parameters of optical density and wavelengths used were respectively, 0.374 and $490 \mathrm{~nm}$ to $S$. aureus, 0.923 and $492 \mathrm{~nm}$ to $S$. epidermidis, 0.620 and $398 \mathrm{~nm}$ to $S$. mutans and 0.284 and $530 \mathrm{~nm}$ to Candida spp., according to previous procedures established in the Laboratory of Microbiology, School of Dentistry of São José dos Campos, São Paulo State University.

\section{Determination of minimum inhibitory concentration (MIC) and minimum microbicidal concentration (MBC) of essential oil}

In order to determine the minimum inhibitory concentration (MIC) of essential oil of $C$. citratus it was used broth dilution assay. The stock solution of the essential oil was plated in sterile test tubes with sterile distilled water and Tween 80, in accordance with the desired concentration and volume (Allegrini et al., 1973). The solution was stirred for 5 minutes using a Vortex apparatus (Fanem), obtaining a solution with the desired final concentration of essential oil for each species. It is important to emphasize that prior tests were conducted with the essential oil of $C$. citratus in different concentrations in order to determine the best initial concentration for all micro-organisms.

In tissue culture test plates (96 cells) (Costar Corning, New York, USA) were added previously $0.125 \mathrm{ml}$ of BHI or Sabouraud broth in each well. In the first columns of the tissue culture test plates were plated $0.125 \mathrm{ml}$ of solution of essential oil with a concentration previously established for each species. Serial dilutions of essential oils were plated at the plate with the aid of automatic micropipette in order to represent 1/2,1/4, 1/8,1/16, 1/32, 1/64 and $1 / 128$ of the initial concentration. In sequence, it was added to all wells of the plate $0.0125 \mathrm{ml}$ of standardized suspension $\left(10^{6}\right.$ viable cells $\left./ \mathrm{ml}\right)$ of each strain of Staphylococcus spp., Streptococcus mutans and Candida spp. The assay was established on the basis of NCCLS (2004). The tests were performed 
in duplicate. The control group consisted of $0.125 \mathrm{ml}$ of Sabouraud broth and $0.125 \mathrm{ml}$ of sterile distilled water with Tween 80 in the same dilutions used in the solution of essential oil and $0.0125 \mathrm{ml}$ of the suspension of micro-organisms.

After incubation for 24 hours at $37^{\circ} \mathrm{C}$ for Candida spp. and Staphylococcus spp. and Streptococcus mutans for 24 hours at $37^{\circ} \mathrm{C}$ in $\mathrm{CO}_{2}$ incubator, the reading was done by visual observation of the turbidity of the medium. It was considered the minimum inhibitory concentration (MIC) the lowest concentration of essential oil tested, able to inhibit microbial growth in broth.

In the determination of the minimum microbicidal concentration (MBC) of essential oil of C. citratus, three inoculations of the previous test, which showed no growth in broth, were placed on Sabouraud dextrose agar plates for determining the minimum fungicidal concentration of Candida spp. and $\mathrm{BHI}$ agar to determine minimum bactericidal for Staphylococcus spp . and Streptococcus mutans. For this, $0.1 \mathrm{ml}$ of inoculum was plated on Sabouraud dextrose agar or $\mathrm{BHI}$ agar. After an incubation period of 48 hours at $37^{\circ} \mathrm{C}$ for Candida spp. and Staphylococcus spp. and S. mutans 48 hours at $37^{\circ} \mathrm{C}$ in $\mathrm{CO}_{2}$ incubator, the colony growth was observed for each species. Herein, the time period of 48 hours was applied since the growth on solid medium is slower and visualization of the colonies is clearer after 48 hours. Minimum microbicidal concentration was defined as the lowest concentration of essential oil tested able to completely inhibit microbial growth on solid medium in Petri dishes. Finally, in order to guarantee the reproducibility of the assays, duplicate tests were performed even at different days.

Evaluation of the effects of essential oil of Cymbopogon citratus (DC) Stapf. on the biofilm formed on acrylic resin disc for standard strains of $C$. albicans, S. mutans and S. aureus

There were used 148 acrylic resin discs, represented by discs for making ocular prosthesis with pin, having diameter of $11 \mathrm{~mm}$ (Clássico Articles Dental Ind. Ltd.) which were sterilized by gamma camera (Cobalt 60) for 6 hours with 20 kGy (Embrarad, São Paulo, Brazil). The micro-organisms species were divided in the following groups: $\mathrm{G} 1$ (C. albicans); G2 (S aureus); G3 (S. mutans); G4 (C. albicans and $S$. aureus ); G5 (C. albicans and $S$. mutans); G6 (S. aureus and S. mutans) and G7 (C. albicans, S. aureus and S. mutans). For each group there were used 12 acrylic resin discs for treatment with essential oil and 12 for control group.

For biofilm formation in vitro, there were used tissue culture test plates with 24 wells (Costar Corning, New York, EUA). The acrylic resin discs were placed in wells of the first rows with $2 \mathrm{ml}$ of brain heart infusion broth $(\mathrm{BHI})$ with $5 \%$ sucrose (Synth, Brasil). For the formation of biofilms it was inoculated $0.1 \mathrm{ml}$ standard suspensions with optical density relative to $10^{6} \mathrm{cell} / \mathrm{s} / \mathrm{ml}$ of the each micro-organism used isolated or in associations.

The acrylic resin discs used in the tests were incubated for 5 days at $37^{\circ} \mathrm{C}$ and for groups with $S$. mutans in microaerobic conditions. After 5 days of biofilm growth, the biofilms in acrylic resin discs were transferred to the second row of 24 wells of the plate and immersed in $2 \mathrm{ml}$ of saline phosphate solution (PBS) with $\mathrm{pH} 7.4$ and washed to remove loosely bound material. After this procedure, the acrylic resin discs were transferred to solution containing the essential oil of $C$. citratus, prepared in accordance with the minimum microbicidal concentration for each species. The following tests were shaken for $5 \mathrm{~min}$ in an orbital shaker. For the control group, the acrylic resin discs were plated in water with Tween 80 for the same period of time. After the stirring time, the acrylic resin discs were plated in tubes containing $10 \mathrm{ml}$ of sterile PBS and brought to ultrasonic homogenizer (Sonoplus HD 2200 - Bandelin Electronic), using the power of $50 \mathrm{~W}$ per 30 seconds in order to disperse the biofilm (Paradella et al., 2009, Pereira et al., 2011). From the obtained solution, serial dilutions were performed, of which $0.1 \mathrm{ml}$ aliquots were plated in duplicate on Sabouraud dextrose agar with chloramphenicol $(0.1 \mathrm{mg} / \mathrm{ml}$ medium $)$ for the strain of $C$. albicans, mannitol agar for $S$. aureus and mitis salivarius bacitracin sucrose $5 \%$ (MSBS) agar for $S$. mutans. The micro-organisms were incubated at $37^{\circ} \mathrm{C}$ for 48 hours, and $5 \% \mathrm{CO}_{2}$ for groups with S. mutans. After 48 hours, the numbers of colony forming units (CFU/ml) were determined for each acrylic resin discs and transformed into logarithm $(\log 10)$ and analyzed by $t$ Student statistical test by considering significance level with $p \leq 0.05$.

\section{RESULTS}

Determination of minimum inhibitory concentration (MIC) of essential oil of Cympopogon citratus (DC) Stapf.

The essential oil of $C$. citratus showed bacteriostatic activity to all strains of Staphylococcus spp. and S. mutans in the different concentrations. The MIC was $0.25 \%$ up to $80 \%$ to strains of $S$. aureus and $0.125 \%$ up to $60 \%$ to the strains of $S$. epidermis. For S. mutans, the concentration of $0.25 \%$ of essential oil of $C$. citratus inhibited $50 \%$ of strains.

The essential oil of $C$. citratus also showed fungistatic activity to the strains of Candida spp. The minimum inhibitory concentration (MIC) of essential oil of $C$. citratus was $0.062 \%$ up to $70 \%$ to strains of C. albicans and $100 \%$ to the strains of C. tropicalis.

Rev. Bras. PI. Med., Campinas, v.15, n.4, p.474-482, 2013. 
TABLE 1. Percentage of micro-organisms inhibited by the essential oil of Cymbopogon citratus in relation to MIC.

\begin{tabular}{lcccccccc}
\hline \multirow{2}{*}{$\begin{array}{l}\text { Micro-organisms } \\
\text { n=10) for each specie }\end{array}$} & \multicolumn{6}{c}{ Percentage of micro-organisms inhibited by the essential oil ofC. citratus } \\
\cline { 2 - 9 } & $2^{*} \%^{*}$ & $1 \%^{*}$ & $0,5 \%^{*}$ & $0,25 \%^{*}$ & $0,125 \%^{*}$ & $0,062 \%^{*}$ & $0,031 \%^{*}$ & $0,015 \%^{*}$ \\
\hline S. aureus & 100 & 100 & 100 & 80 & 20 & 0 & 0 & 0 \\
S. epidermidis & 100 & 100 & 100 & 100 & 60 & 40 & 0 & 0 \\
S. mutans & 100 & 100 & 100 & 50 & 40 & 10 & 0 & 0 \\
C. albicans & 100 & 100 & 100 & 100 & 100 & 70 & 30 & 0 \\
C. tropicalis & 100 & 100 & 100 & 100 & 100 & 100 & 80 & 20 \\
C. glabrata & 100 & 100 & 100 & 100 & 100 & 50 & 40 & 10 \\
\hline
\end{tabular}

For C. glabrata, $50 \%$ of the strains showed a MIC of $0.062 \%$ of essential oil (Table 1 ). In the control group, there was bacterial growth for all strains.

Determination of the minimal microbicidal concentration (MMC) of essential oil of Cympopogon citratus (DC) Stapf.

The $C$. citratus showed microbicidal activity against all tested strains. The MMC of the essential oil of C. citratus was $0.5 \%$ up to $80 \%$ to strains of S. aureus, $0.125 \%$ up to $90 \%$ to the strains of $S$. epidermidis, $0.5 \%$ up to $70 \%$ to the strains of $S$. mutans, and $0.125 \%$ up to $90 \%$ to the strains of $C$. albicans, $100 \%$ to the strains of C. tropicalis and $60 \%$ to the strains of C. glabrata (Table 2). In the control group there was microbiological growing for all strains tested.

Assessment of the effects of essential oil of Cymbopogon citratus (DC) Stapf.. on biofilm The essential oil of C. citratus at $0.062 \%$ showed antimicrobial activity against biofilms formed by $C$. albicans isolated or in associations. There was significant statistical differences among groups of essential oil and control for the biofilms formed by $C$. albicans $(p=0.0001), C$. albicans and $S$. aureus ( $p$ $=0.0001), C$. albicans and $S$. mutans $(p=0.0001)$,
C. albicans, $S$. aureus and S. mutans $(p=0.001)$. These results are shown in Figure 1.

The essential oil of C. citratus at $0.5 \%$ showed antimicrobial activity against biofilms formed by $S$. aureus isolated or in associations. There was significant statistical difference among the groups essential oil and control for the biofilms formed with $S$. aureus $(p=0.0001), S$. aureus and $C$. albicans $(p=0.001), S$. aureus and $S$. mutans $(p=0.0001)$, $S$. aureus, $C$. albicans and $S$. mutans $(p=0.0001)$. These results are shown in Figure 2.

Treatment with the essential oil of $C$. citratus at $0.5 \%$ for the biofilm produced by $S$. mutans showed antimicrobial activity on the biofilm formed isolated or in associations. There was significant statistical difference between groups of essential oil and control group for the biofilms formed by $S$. mutans $(p=0.0001), S$. mutans and $C$. albicans $(p$ $=0.004)$, $S$. mutans and $S$. aureus $(p=0.013)$. In the associations of $C$. albicans, $S$. aureus and $S$. mutans the difference was not statistically significant $(p=0.461)$. These results are shown in Figure 3.

Analyzing all control groups, it can be observed that $C$. albicans and $S$. aureus had the highest number of CFU/ml when the biofilm was formed by the organism isolated in relation to the biofilm formed by the association of these two micro-

TABLE 2. Percentage of micro-organisms inhibited by the essential oil of Cymbopogon citratus in relation to MMC

\begin{tabular}{lcccccccc}
\hline \multirow{2}{*}{$\begin{array}{l}\text { Micro-organisms } \\
\text { n=10) for each specie }\end{array}$} & \multicolumn{6}{c}{ Percentage of dilution of the essential oil ofC. citratus ${ }^{*}$} \\
\cline { 2 - 9 } & $2^{*}$ & $1^{*}$ & $0,5 \%^{*}$ & $0,25 \%^{*}$ & $0,125 \%^{*}$ & $0,062 \%^{*}$ & $0,031 \%^{*}$ & $0,015 \%^{*}$ \\
\hline S. aureus & 100 & 100 & 80 & 20 & 0 & 0 & 0 & 0 \\
S. epidermidis & 100 & 100 & 100 & 100 & 90 & 10 & 0 & 0 \\
S. mutans & 100 & 100 & 70 & 20 & 10 & 0 & 0 & 0 \\
C. albicans & 100 & 100 & 100 & 100 & 90 & 10 & 0 & 0 \\
C. tropicalis & 100 & 100 & 100 & 100 & 100 & 80 & 20 & 0 \\
C. glabrata & 100 & 100 & 100 & 100 & 60 & 40 & 0 & 0 \\
\hline
\end{tabular}

Rev. Bras. PI. Med., Campinas, v.15, n.4, p.474-482, 2013. 


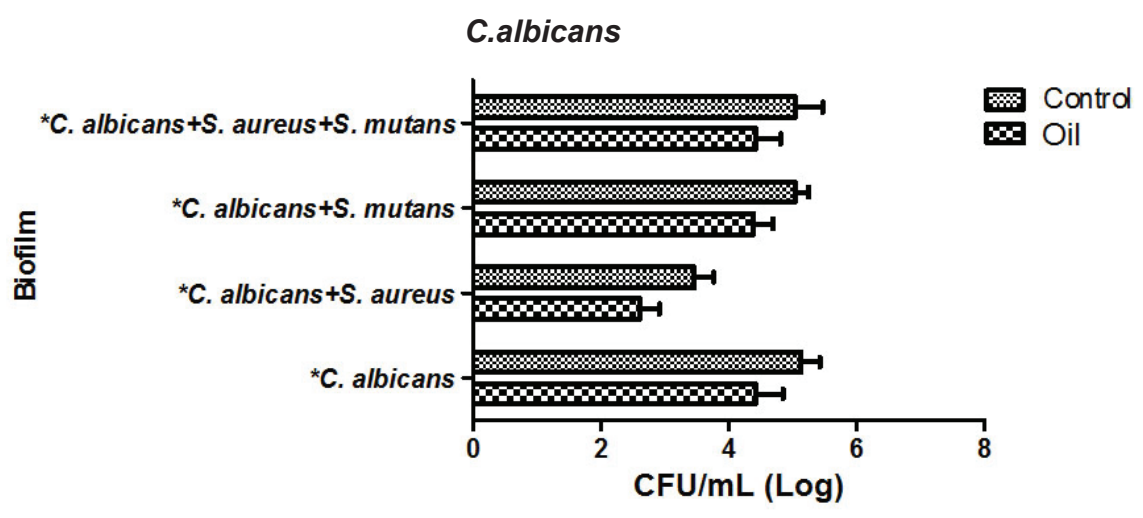

FIGURE 1. Mean and standard deviation of data of CFU/ml (Log) obtained in the testing of $C$. albicans biofilms isolated on in associations. *Statistical difference $(p \leq 0,05)$

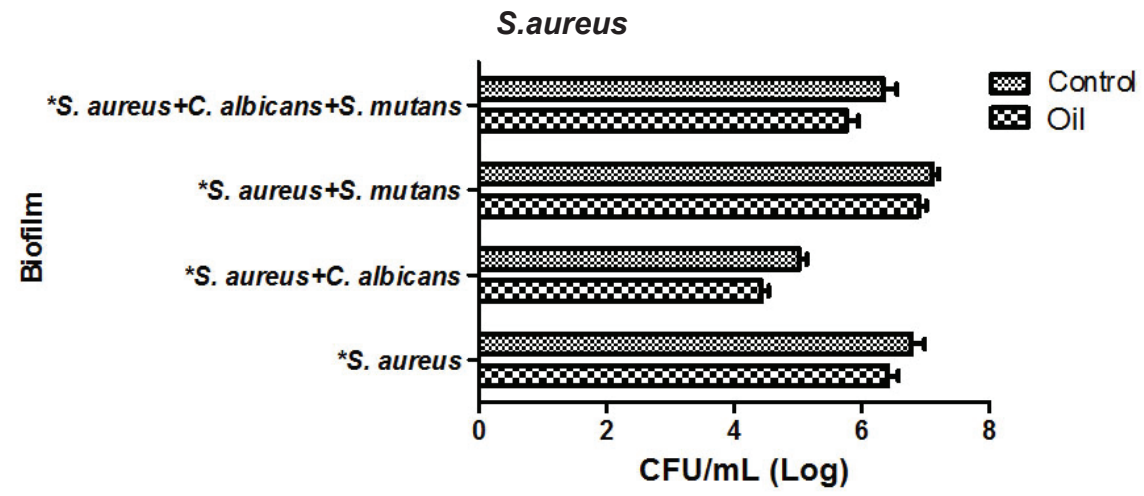

FIGURE 2. Mean and standard deviation of data of CFU/ml (Log) obtained in the testing of $S$. aureus biofilms isolated on in associations. *Statistical difference $(p \leq 0,05)$

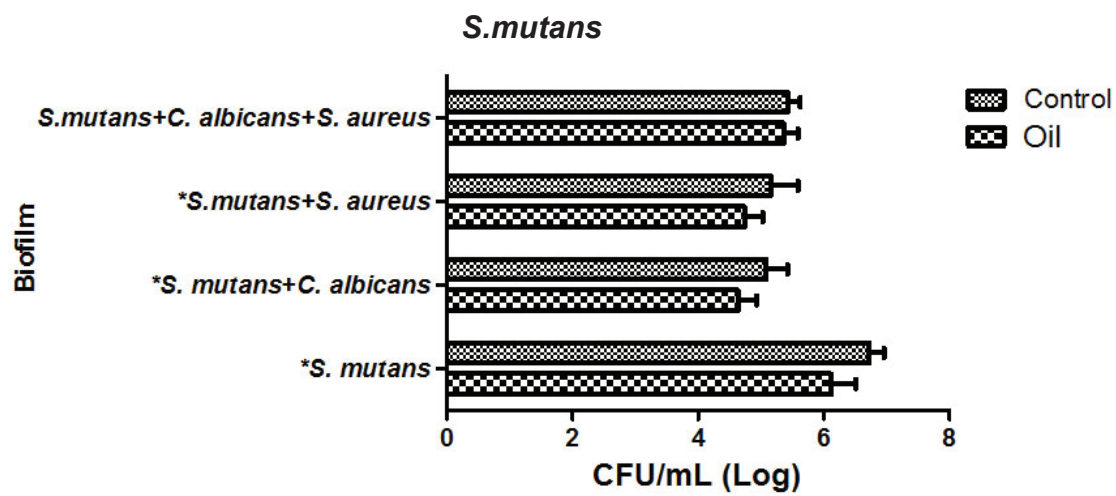

FIGURE 3. Mean and standard deviation of data of CFU/ml (Log) obtained in the testing of S. mutans biofilms isolated on in associations. *Statistical difference $(p \leq 0,05)$

organisms. However, when it was considered the association between Candida albicans and $S$. aureus with $S$. mutans, the number of CFU/ml was similar to the isolated biofilm (Figure 3).

\section{DISCUSSION}

Medicinal plants have been used throughout the world in popular medicine for medical purposes for thousands of years. Recently, they are receiving 
considerable attention due to their pharmacological effects such as antimicrobial, anticarcinogenic, and antioxidant properties (Balunas \& Kinghorn, 2005). Natural products have been used as a major source of innovative and effective therapeutic agents throughout human history, offering a diverse range of structurally distinctive bioactive molecules (Jeon et al., 2011). Although numerous bioactive substances have been isolated from plants and their modes of action have been investigated, relatively few studies have been done in the dentistry field (Jeon et al., 2011, Sakagami et al., 1999).

Infectious diseases caused by bacteria, fungi, viruses and parasites are still a major threat to public health, despite the tremendous progress in human medicine. Their impact is particularly large in developing countries due to the relative unavailability of medicines and the emergence of widespread drug resistance (Nostro et al., 2005). Secondary metabolites produced by plants constitute a major source of bioactive substances. The scientific interest in these metabolites has increased today with the search of new therapeutic agents from plant source, due to the increasing development of the resistance pattern of micro-organisms to most currently used antimicrobial drugs (Mbosso et al., 2010).

Cymbopogon citratus is a medicinal plant with antimicrobial properties. For the extraction of the active ingredients of this plant there are different methods of preparation of the leaves of $C$. citratus. Among them include: hydroalcoholic, glycolic extract and essential oil. In this study, the choice was taken for the preparation of essential oil from leaves of Cymbopogon citratus (DC) Stapf.

According to Onawunmini (1989), the essential oil of $C$. citratus has three main components in its composition, which are: alpha citral (geranial), beta-citral (neral) and myrcene. That study showed that alpha and beta citral showed antimicrobial activity against Gram-positive and Gram-negative bacteria. However, the component myrcene showed no antimicrobial activity alone. Barbosa et al. (2008) evaluated the concentration and the chemical composition of the essential oils obtained from 12 different samples of Cymbopogon citratus. The following compounds were found: neral, geranial, limonene, citronellal, myrcene, and geraniol.

In the current study, it was evaluated the action of essential oil of Cymbopogon citratus (DC) Stapf. through the minimum inhibitory concentration (MIC) and incubation on agar, to determine the minimal microbicidal concentration (MMC). Effects were observed for antibacterial and antifungal essential oil of $C$. citratus for all strains of Staphylococcus spp., Streptococcus mutans and Candida spp.

Antimicrobial effects by using the essential oil of C. citratus, was found by Onawunmi (1989), who analyzed the action of essential oil at $0.05 \%$ to Staphylococcus aureus, Bacillus subtilis and Escherichia coli by agar diffusion method. That author observed diameter inhibition zone of 15 $\mathrm{mm}$ for $E$. coli, and $32 \mathrm{~mm}$ for $B$. subtilis and $S$. aureus, concluding that the essential oil of $C$. citratus showed good antimicrobial activity even at low concentrations. Hammer et al. (1999), also using the agar dilution method, evaluated the effect of essential oil of $C$. citratus on the following micro-organisms: Acinetobacter baumannii, Aeromonas veronii, Candida albicans, Enterococcus faecalis, Escherichia coli, Klebsiella pneumoniae, Pseudomonas aeruginosa, Salmonella enterica, Serratia marcescens and Staphylococcus aureus. In the work of Hammer et al. (1999) it was found significant antimicrobial action of oil of $C$. citratus for all organisms analyzed. The MIC of essential oil of C. citratus was $0.06 \%$ for $S$. aureus and C. albicans. These results are consistent with data obtained in this work, where the MIC for C. albicans was $0.031 \%$ and for $S$. aureus $0.125 \%$. Wannissorn et al. (2005) found 32 antimicrobial effects of essential oils from local plants or cultivated in Thailand, using the agar diffusion method on strains of Salmonella spp., Escherichia coli and Clostridium perfringens. Among the oils tested, $C$. citratus showed inhibition of $24 \mathrm{~mm}, 12 \mathrm{~mm}$ and $90 \mathrm{~mm}$, respectively, for $S$. typhimurium, E. coli and C. perfringens.

According to Hammer et al. (1999), the comparison of data obtained in different studies is difficult because one must take into account that the composition of essential oil plant can vary according to: local conditions and climate of the environment, the technique of extraction and utilization of oil, and the choice of microbial tests.

Although different methodologies and different organisms analyzed, it was observed that the essential oil of $C$. citratus was effective for all tested micro-organisms used in this work and other studies cited previously.

Biofilms represent the predominant type of microbial growth in nature and are crucial for developing infections, since they serve as niche for pathogens and are associated with high levels of antimicrobial resistance (Kuhn et al. 2002). According to Jeon et al. (2011), Kirkpatrick et al. (2000) biofilm has a number of advantages to the organism, such as better communication between cells, which facilitates the biochemical and the increased proliferation, access to resources and niches that could not be achieved by single cells, and collective defense against the action of antimicrobial agents.

In the present study, it was also analyzed the effect of essential oil of $C$. citratus (DC.) Stapf. on the

Rev. Bras. PI. Med., Campinas, v.15, n.4, p.474-482, 2013. 
biofilm formed in acrylic resin discs, using standard strains of $S$. aureus, S. mutans and C. albicans, isolated or in associations. After the treatment of the biofilm with essential oil of $C$. citratus, the suspension containing the microbial cells were seeded in petri dishes containing selective culture media for each species studied. The essential oil of C. citratus showed antimicrobial activity against all micro-organisms studied when arranged in single and mixed biofilms, except for S. mutans, when associated with $C$. albicans and $S$. aureus. Also, it was observed that in mixed biofilms of $C$. albicans and $S$. aureus, there was a reduction in $\mathrm{CFU} / \mathrm{ml}$ (Log) of C. albicans and S. aureus in relation to the isolated biofilms and biofilms with associations. Baena-Monroy et al. (2005) reported that both micro-organisms, $S$. aureus and $C$. albicans, have high adhesion capacity in oral mucosa of the host, causing great competition between these two micro-organisms.

On the count of CFU/ml (Log) of $S$. mutans, when organized in biofilm mixed with $S$. aureus and $C$. albicans, there was no significant statistical difference between the group treated with oil of $C$. citratus and control groups. According to Dunne (2003), the microbicidal effect of an antibiotic in the biofilm occurs only on the microorganisms positioned in the outermost layer of the biofilm, leaving healthy ones that are present in the inner layer. Those data suggest that the formation of a biofilm composed of $S$. mutans, $S$. aureus and C. albicans, the micro-organism S. mutans may have occupied the position of the innermost biofilm and thus become more resistant to essential oil of $C$. citratus.

In conclusion, this investigation of medicinal plant described here shows very promising activity in the area of antimicrobial agents. The essential oil of $C$. citratus showed bacteriostatic activity, fungistatic and microbicide on all strains of Staphlylococcus spp., S. mutans and Candida species studied in this work and also showed antimicrobial activity against $S$. aureus, $S$. mutans and $C$. albicans when arranged in single and mixed biofilms. However, further pharmacological and toxicity studies are necessary to help the understanding the in vitro action of the essential oil currently in study.

\section{ACKNOWLEDGEMENTS}

The author Rosilene B. de Aguiar Almeida is grateful to CAPES (Coordenação de Aperfeiçoamento de Pessoal de Nível Superior) for the scholarship provided. This work was supported by FAPESP (Fundação de Amparo a Pesquisa do Estado de São Paulo), grant 2007/54997-5.

\section{REFERENCE}

ALLEGRINI, M.; SIMÉON, M., MAILLOS H; BOILOOT, A. Ėmulsions et applications en microbiologie. Travaux de la Société de Pharmacie de Montpellier, 33, 73-86, 1973.

ARENDORF, T.M.; WALKER, D. M. The prevalence and intra-oral distribution of Candida albicans in man. Archives Oral Biology. 25, 1-10, 1980.

BABA, T.; BAE, T., SCHNEEWIND, O; TAKEUCHI, F.; HIRAMATSU, K. Genome Sequence of Staphylococcus aureus strain newman and comparative analysis of Staphylococcal genomes: polymorphism and evolution of two major pathogenicity islands. Journal of Bacteriology.190, 300-310, 2008.

BAENA-MONROY, T.B.; MALDONATO, V.M.; MARTINEZ, F.F.; BARRIOS, B.A.; QUINDOS, G; VARGAS, L.O.S. Colonización por Candida albicans, Staphylococcus aureus y Streptococcus mutans em pacientes portadores de prótesis dentales. Journal of Oral Pathology and Medicine. 10, 27-29, 2005.

BALUNAS, M.J.; KINGHORN, A.D. Drug discovery from medicinal plants. Life Sciences, 78, 431-441, 2005.

BARBOSA, L.C.; PEREIRA U.A.; MARTINAZZO, A.P.; MALTHA, C.R.; TEIXEIRA, R.R.; MELO, E C. Evaluation of the chemical composition of Brazilian commercial Cymbopogon citratus (DC) Stapf. samples. Molecules, 27;13(8):1864-74, 2008.

BURTON, G.R.W; ENGELKIRK, P.G., 2004. Microbiology for the health sciences. $7^{a}$ ed. USA. 418p.

CIMANGA, K.; KAMBU, K; TONA, L; APERS, S.; BRUYNE, T.; HERMANS, N. Correlation between chemical composition and antibacterial activity of essential oils of some aromatic medicinal plants growing in the Democratic Republic of Congo. Journal of Ethnopharmacology, 79, 213-220, 2002.

CLARDY J.; WALSH, C. Lessons from natural molecules. Nature, 432, 829-837, 2004.

CLEVENGER, J. F. Apparatus for the determination of volatile oil. Journal of the American Pharmaceutical Association, 17, 345-349, 1928.

COS, P.; VLIETINCK, A.J; DIRK, VANDEN BERGHE, MAES, L. Anti-infective potential of natural products: How to develop a stronger in vitro 'proof-of-concept'. Journal of Ethnopharmacology, 106, 290-30, 2006.

CUÉLLAR-CRUZ, M.; LÓPEZ-ROMERO, E.; VILLAGÓMEZ-CASTRO ,J.C.; RUIZ-BACA, E. Candida species: new insights into biofilm formation. Future Microbiology, 7,755-71, 2012.

CUESTA, A.I.; JEWTUCHOWICZ, V.M.; BRUSCA, M.I.; MUJICA, M.T.; ROSA, A.C. Antibiotic susceptibility of Staphylococcus aureus isolates in oral mucosa and pockets of patients with gingivitis-periodontitis. Acta Odontol Latinoamerican. 2011;24(1):35-40.

DUNNE, W.M. Bacterial Adhesion: Seen Any Good Biofilms Lately? Clinical Microbiology Reviews. 15(2), 155-166, 2003.

DUARTE, M.C.T.; FIGUEIRA, G.M.; SARTORATTO, A; REHDER, V.L.G; DELARMELINA, C. Anti-Candida activity of Brazilian medicinal plants. Journal of Ethnopharmacology, 97(2):305-11, 2005.

FERNANDES, C.N., SOUZA, H.F.; OLIVERIA, G.; COSTA, J.G.M; KERNTOPF, M.R; CAMPOS, A.R. Investigation of the mechanisms underlying the gastroprotective effect

Rev. Bras. PI. Med., Campinas, v.15, n.4, p.474-482, 2013. 
of Cymbopogon citratus essential oil. Journal of Yong Pharmacists, 4(1):28-32, 2012.

JEON, J.G.; ROSALEN P.L.; FALSETTA, M.L.; H. KOO. Natural products in caries research: current (Limited) knowledge challenges and future perspective. Caries Research, 45:243-263, 2011.

GÁlVÉZ, J.L.H; TORRES, I.P.; AGUILAR, O.E.A.; LARA, M.L. Estudio del efecto diurético de la hoja de Cymbopogon citratus en modelo de ratas. Revista Cubana Plantas Medicinais, 3(2),79-82, 1998.

HAMMER, K.A.; CARSON, C.F.; RILEY, T.V. Antimicrobial activity of essential oils and other plant extracts. Journal Applied Microbiology, 86,985-990, 1999.

HELLER, D.; SILVA-BOGHOSSIAN, C.M.; SOUTO R. M, COLOMBO A.P.V. Subgingival microbial profiles of generalized aggressive and chronic periodontal diseases. Archives of Oral Biology, 57(7):973-80, 2012.

IRKIN, R., KORUKLUOGLU, M. Effectiveness of Cymbopogon citratus L. essential oil to inhibit the growth of some filamentous fungi and yeasts. Journal Medicinal Food, 12(1):193-7, 2009.

KHAN, M.S.; AHMAD, I. Biofilm inhibition by Cymbopogon citratus and Syzygium aromaticum essential oils in the strains of Candida albicans. Journal of Ethnopharmacology, 140(2):416-23, 2012.

KIRKPATRICK, W.R.; LÓPEZ-RIBOT, J.L.; MCATEE, R.K.; PATTERSON, T.F. Growth competition between Candida dubliniensis and Candida albicans under broth and biofilm growing conditions. Journal Clinical Microbiology, 38(2), 902-904, 2000.

KUHN, D.M.; CHANDRA, J.; MUKHERJEE, P.K.; GHANNOUM, M.A. Comparison of biofims formed by Candida albicans and Candida parapsilosis on bioprosthetic surfaces. Infection and Immunity, 70,878-888, 2002.

LEWINSOHN, E., DUDAI; N., TADMOR, Y.; KATZIR, I.; RAVID, U.; PUTIEVKY, E.; JOEL, D.M. Histochemical localization of citral accumulation in lemongrass leaves Cymbopogon citratus (DC) Stapf.. Annals of Botany, 81, 35-39, 1998.

MARSH, P.D. Dental plaque as a microbial biofilm. Caries Research, 38(3), 204-211, 2004.

MBOSSO, E.J.T.; NGOUELA S.; NGUEDIA, J. C. A; BENG V. P.; ROHMER M.; TSAMO E. In vitro antimicrobial activity of extracts and compounds of some selected medicinal plants from Cameroon. Journal of Ethnopharmacology, 128, 476-481. 2010.

NOSTRO A, ROCCARO AS, BISIGNANO G, MARINO A, CANNATELLI MA, PIZZIMENTI FC, OKEKE, I.N., LAXMANINARAYAN, R., BHUTTA, Z.A., DUSE, A.G., JENKINS, P., O'BRIEN, T.F., PABLOS-MENDEZ, A., KLUGMAN, K.P. Antimicrobial resistance in developing countries. Part 1: recent trends and current status. Lancet Infectious Diseases ,5, 481-493. 2005.

MORAN, J.; ADDY, M.; ROBERTS, SA. Comparison of natural product, triclosan and chlorhexidine muthrinses on 4-day plaque regrowth. Journal Clinical Periodontal, 9(8),578-582,1992.

NIKAWA H.; EGUSA H.; MAKIHIRA S.; YAMASHIRO H.; FUKUSHIMA H.; C. JIN, NISHIMURA M.; PUDJI R. R; HAMADA, T. Alteration of the coadherence of Candida albicans with oral bacteria by dietary sugars. Oral
Microbiology and immunology, 16, 279-283, 2001. NOSTRO A; ROCCARO A.S; BISIGNANO G; MARINO A; CANNATELLI, M.A.; PIZZIMENTI, F.C.; OKEKE, I.N.; LAXMANINARAYAN, R., BHUTTA, Z.A.; DUSE, A.G.; JENKINS, P.; O'BRIEN, T.F.; PABLOS-ONAWUNMI, G. Evaluation of the antifungal activity of Lemon grass oil. Pharmaceutical Biology, 27, 121-26,1989.

O'SULLIVAN, J.M.; JENKINSON, H.F.; CANNON, R.D. Adhesion of Candida albicans to oral streptococci is promoted by selective adsorption of salivary proteins to the streptococcal. Microbiology,146,41-48, 2000.

O'TOOLE, G.A.; KAPLAN, H.; KOLTER, R. Biofilm formation as microbial development. Annual Review Microbiology, 54(1), 49-79, 2000.

PARADELLA, T.C.; KOGA-ITO C.Y.; JORGE, A.O. In vitro antibacterial activity of adhesive systems on Streptococcus mutans. Journal Adhesive Dentistry, 11(2):95-9, 2009.

PEREIRA CA, ROMEIRO RL, COSTAAC, MACHADOAK, JUNQUEIRA JC, JORGE AO. Susceptibility of Candida albicans, Staphylococcus aureus, and Streptococcus mutans biofilms to photodynamic inactivation: an in vitro study. Lasers in Medical Science, 26(3):341-8, 2011.

PUATANACHOKCHAI, R.; KISHIDA, H.; DENDA, A.; MURATA, N.; KONISHI, Y.; VINITKETKUMNUEN, U. Inhibitory effects of lemon grass (Cymbopogon citratus, Stapf) extract on the early phase of hepatocarcinogenesis after initiaton with diethylnitrosamine in male fisher 344 rats. Cancer Letter, 183(1),9-15, 2002.

RASMUSSEN, T.B.; GIVSKOV, M. Quorum-sensing inhibitors as antipathogenic drugs. International Journal of Medical Microbiology, 296, 149-161, 2006.

ROJAS A.; HERNANDEZ L.; PEREDA-MIRANDA, R; MATA, R. Screenig for antimicrobial activity of crude drug extracts and pure natural products from Mexican medicinal plants. Journal of Ethnopharmacology, 35, 275-83,1992.

SAKAGAMI, H.; OI, T.; SATOH, K. Prevention of oral diseases by polyphenols (review). In vivo 13, 155-171, 1999.

SANTORO, G.F.; CARDOSO, M.G.; GUIMARÃES, L.G.L.; FREIRE, J.M.; SOARES, M.J. Anti-proliferative effect of the essential oil of Cymbopogon citratus (DC) Stapf (lemongrass) on intracellular amastigotes, bloodstream trypomastigotes and culture epimastigotes of Trypanosoma cruzi (Protozoa: Kinetoplastida). Parasitol 134:1649-56, 2007.

SEN, B.H.; SAFAVI, K.E.; SAPANGBERG, L.S.W. Growth patterns of Candida albicans in relation to radicular dentin. Oral Surgery, Oral Medicine, Oral Pathology Oral radiology and endodontics, 84(1), 68-73, 1997.

VERKMAN, A.S. Drug discovery in academia. American of Journal Physiology, Cell Physiology, 286, 465474, 2004.

WANNISSORN, B.; JARIKASEM, S.; SIRIWANGCHAI, T.; THUBTHIMTHED, S. Antibacterial properties of essential oils from Thai medicinal plants. Fitoterapia, 76, 233-236, 2005.

WERTHEIM, H.F.L; MELLES, D.C.; VOS, M.C.; VAN LEEUWEN, W.; VAN BELKUM, A; VERBRUGH, H.A.; NOUWEN, J.L. The role of nasal carriage in Staphylococcus aureus infections. The Lancet Infections Diseases, 5, 751-62, 2005. 